\title{
Metakalbiniai komentarai kaip internetinio naujažodžių diskurso elementas
}

\author{
JURGITA GIRČIENÉ \\ Lietuvos edukologijos universitetas, T. Ševčenkos g. 31, LT-03111 Vilnius \\ El. paštas: jurgita.girciene@vpu.lt
}

\begin{abstract}
Straipsnyje, remiantis kalbos vartotojų internete pateiktais naujažodžių - naujųjų darinių su elementu (-)tinkl- ir ịvairiašaknių dubletinių naujųjų skolinių bei kitų sinoniminių jų atitikmenų - metakalbiniais komentarais, nagrinëjami ịvairūs internetinio naujažodžių diskurso klausimai: įvairiafunkcius naujažodžius įvairiažanriuose elektroniniuose tekstuose lydinčių metakalbinių komentarų paskirtis, kalbos vartotojų metakalboje atsiskleidžiantys naujažodžių integracijos ị tekstą, socializacijos bei leksikalizacijos, naujadaros procesų atspindžiai, naujažodžių diskurso dalyvių požiūris ị naujụjų skolinių norminimą, skolintų bei lietuviškų naujažodžių kokybę ir kt.
\end{abstract}

Raktažodžiai: naujažodis, naujasis skolinys, naujasis darinys, metakalbinis komentaras, internetas

\begin{abstract}
IVADAS
Internetas atvèrè vartus visuotiniam naujažodžių diskursui (1). Čia gausiai kuriami, diskutuojami, skleidžiami (ar nepraleidžiami) postmodernybei itin būdingi nauji žodžiai. Iprasta, kad kalbą, taigi ir naujus žodžius, nagrinėja specialistai - kalbininkai. Tačiau apie visuomenei gerai matomą dabartinị itin spartų leksikos kismą, gausiai besirandančius naujažodžius nuomonę aktyviai reiškia ir kalbos vartotojai - ypač apie naujuosius skolinius bei naujaisiais dariniais išreikštus lietuviškus jų atitikmenis. Globalusis tinklas atvèrè kelią viešoms kalbinès bendruomenès diskusijoms, sudemokratino ir pagreitino naujųjų skolinių atitikmenų paieškos bei leksikos variantų konkurencijos, socializacijos ir leksikalizacijos procesus. Būtent todèl informacinè ir ypač komunikacinè interneto (2) erdvė yra ypač tin-

(1) Naujažodžiu diskursas suprantamas kaip viešojo diskurso dalis, kurios objektas yra naujažodžiai [plg. 26, 4, 7].

(2) Internetas, atsižvelgiant ì paplitimą, pasaulio komunikacijos specialistų laikomas pagrindine, atskira naujaja medija. Jos išskirtiniai bruožai: privačiosios ir viešosios erdvės funkcijos, interaktyvumas, daug didesnè galimybè auditorijai atlikti siuntejo vaidmeni - internetas niekam nepriklauso, nèra kontroliuojamas ir prižiürimas iš vieno centro. Pradedant vadinamuoju antrosios kartos internetu (web 2.0), čia sudarytos daugiakryptés komunikacijos sąlygos. Vienas naujujų interneto bruožų - didelès, su niekuo anksčiau nepalyginamos galimybès auditorijai dalyvauti kuriant ir skleidžiant pranešimus - yra svarbiausia pastarojo meto interneto ir apskritai naujujjų medijų raidos tendencija, ịvardijama socialinių mediju (visas jų turinys yra sukurtas vartotojų) terminu [plačiau žr. 27, 37 ir t. t.].
\end{abstract}


kama tirti kalbos vartotojų požiūrị i vadinamuosius ypatingus žodžius - naujažodžius, dar (iki galo) neįsitvirtinusius vartosenoje ir kalbos sistemoje, dažnai tarpusavyje konkuruojančius.

Kalbos vartotojai gali pasitelkti kalbą pačiai kalbai, komunikacinei situacijai ir savo santykiui su jomis komentuoti, taip realizuodami metakalbinę funkciją $[17,14 ; 1]$ (3). Teigiama, kad nekalbininkų metakalbos - kalbejjimo apie kalbą, arba kitaip metakalbinių komentarų ir metakalbinių vienetų su jais, - tyrimas padeda geriau pažinti ne tik pačią kalbą, bet ir kalbinę visuomenès savimonę, todèl jis pravartus ir tradicinei kalbotyrai - leksikologijai, leksikografijai, stilistikai, ir sociolingvistikai, psicholingvistikai, etnolingvistikai bei kt. šakoms [žr. 32, 390; 21, 55]. Metakalbinis komentaras (MK) paprastai suprantamas kaip kalbos, jos vienetų, teksto kalbinès raiškos aptarimas - vertinimas, vartojimo motyvavimas, šaltinio nuoroda ir pan. [žr. 31, 124; 32, 390]. Tai gali būti ịvairios formos bei apimties frazè ar didesnè teksto dalis, apibūdinanti paties teksto kūrèjo arba kitų diskurso dalyvių kalbos vartojimą [5]. MK su komentuojamąja teksto dalimi, pavyzdžiui, žodžiu, sudaro metakalbinį vienetą $[31,124 ; 32,390 ; 36,62]$ ir atlieka metakalbinę funkciją [plg. 12, 249-253].

Šio straipsnio objektas - naujažodžių: naujųų darinių su elementu (-)tinkl- ir ịvairiašaknių dubletinių naujųjų skolinių bei kitų sinoniminių jų atitikmenų metakalbiniai komentarai ir metakalbiniai vienetai su jais. Internetiniam naujažodžių diskursui atskleisti neatsitiktinai pasirinkta gausi - per 200 vienetų - įvairiatipių naujažodžių, ịvardijančių būtent globalaus tinklo realijas, imtis. Ji apima: 1) per 120 naujųų darinių, turinčių dèmenị (-)tinkl-, pvz.: tinklalapis, tinklalapynas, tinklaraštija, mikrotinklaraštis, tinklaraščiavimas, tarp kurių vyrauja referentinę, t. y. informacijos perdavimo, funkciją atliekantys ịvairiašaknių naujųjų skolinių atitikmenys, dalis kurių yra kompiuterijos terminai, pvz., tinklaraštis ((ve)blogas), bet esama ir postmodernybei itin būdingų stilistiškai žymètų, emocinę ekspresinę ir kt. funkcijas atliekančių naujųjų darinių, nesietinų su konkrečiais skoliniais, pvz., plepatinklis (4); 2) su minètaisiais naujaisiais dariniais, turinčiais elementą (-)tinkl-, konkuruojančius ppr. referentinę funkciją atliekančiais naujažodžiais išreikštus leksikos variantus (per 80 vienetų) - ịvairiašaknius naujuosius skolinius, tarp kurių vyrauja turintieji šakni blog- (5), ir kitus naujai sukurtus jų atitikmenis, pvz.: blogeris - tinklaraštininkas, tinklarašy (i)s, tinklarašeiva ir asmenraštininkas, dienoraštininkas, dienrašys, inter(net) saitininkas, mintrašys, mintininkas, saitraštininkas ir kt.; vebas - žiniatinklis ir saitynas ir

(3) Remiamasi Romano Jakobsono kalbinès komunikacijos funkcijų klasifikacija, kurioje skiriamos šešios pagrindinès funkcijos: referentinè, metakalbinè, emotyvinè (šiame straipsnyje vartojamas terminas emocine ekspresiné, plg. paties Jakobsono minimus kitus terminus: emotyviné arba ekspresine [17, 10], Simo Karaliūno: ekspresiné-emotyviné [18, 136 ir t. t.]), konatyvinè, fatinè, poetinè. Metakalbinę funkciją Jakobsonas glaustai apibūdina kaip žodžio aiškinimo funkciją [17, 9-17].

(4) Iki 2011 m. rugpjūčio mèn. vartosenoje rasti 123 naujažodžiai su dèmeniu (-)tinkl- [plačiau apie juos žr. 11].

(5) Naujasis skolinys blògas atsinešè per dvidešimt giminiškų svetimžodžių, pvz.: blogeris, blog(o)sfera, vartosenoje taip pat rasta per dešimt bendrašaknių darinių su lietuviškais afiksais, kurių dalis yra aplietuvinti skolinių sinonimai, plg. blòginimas ir blogingas [plačiau apie tai žr. 10]. Taigi vien su šaknimi blog- esama per 30 skolintų naujažodžių. Visi jie turi naujaisiais dariniais su elementu tinklarašt- išreikštų atitikmenų, pvz.: blog(o)sfera - tinklaraštija, bloginimas - tinklaraštinimas [plačiau apie tai žr. 10; 11]. Kiti aktualesni tiriamosios imties įvairiašaknių skolinių ir jų atitikmenų pavyzdžiai: internautas - tinklažmogis ir kt., intranetas - vidinis tinklynas ir kt., netbukas - tinklinukas ir kt., nikas, nikneimas - tinklavardis ir kt., podkastas - tinklalaide ir kt., subnetas - potinklis ir kt., vebmasteris - tinklavaldis ir kt. 
kt. Taigi tiriamųjų metakalbinių vienetų dėmeniu potencialiai gali eiti visų naujažodžių tipų atstovai (6). Metakalbiniai aprašytųjų naujažodžių komentarai rinkti iš informacinès (tinklalapių, tinklaraščių straipsnių ir pan.) ir komunikacinės (diskusijų forumų, straipsnių komentarų ir pan.) interneto erdvės tekstų. Iš viso tirta per 600 metakalbinių vienetų, iš jų parengto duomenyno apimtis - per 250000 spaudos ženklų. Remiantis šia tyrimo medžiaga straipsnyje nagrinėjami šie internetinio naujažodžių diskurso klausimai: ịvairiafunkcius naujažodžius įvairiažanriuose elektroniniuose tekstuose lydinčių metakalbinių komentarų paskirtis, svarba, komentuojamųjų naujažodžių pobūdis, kalbos vartotojų metakalboje atsiskleidžiantys naujažodžių integracijos ị tekstą, socializacijos bei leksikalizacijos, naujadaros procesų atspindžiai, naujažodžių diskurso dalyvių požiūris ị naujųjų skolinių norminimą, skolintų bei lietuviškų naujažodžių kokybę - tinkamumą realijoms ịvardyti.

Tai pirmasis ne tik internete pateikiamų, bet ir apskritai metakalbinių komentarų, kurių objektas yra lietuvių kalbos naujažodžiai kaip visuma, tyrimas. Metakalbiniai naujažodžių komentarai fragmentiškai minimi svarstant naujų žodžių integracijos ị rašytinį tekstą klausimus [6], apie juos užsimenama ir naujuosius skolinius bei (naujaisiais dariniais) išreikštus jų atitikmenis, funkcionuojančius rašytinejje vartosenoje, nagrinėjančiuose darbuose [7; 30]. Minimalios informacijos apie metakalbinius naujažodžių komentarus esama ir kalbos dabartiškumo nuorodų $[31,125,127-130]$ bei nekalbininkų požiūrio ị žodžio vartojimą $[32,392]$ tyrimuose, paremtuose iš esmès rašytine ir fragmentiškai sakytine vartosena.

\section{NAUJAŽODŽIO REIKŠMĘ AIŠKINANTYS MK}

Kokybinė pasirinktos imties naujažodžių, ịvardijančių žiniatinklio realijas, MK analizė atskleide, kad pagal paskirti metakalbinius komentarus galima skirti ị dvi pagrindines grupes: 1) aiškinančius naujažodžio reikšmę, 2) aptariančius naujažodžio vertę.

Padedantys dekoduoti tekstą, adresatui nežinomą naujažodžio reikšmę aiškinantys MK itin būdingi informacinei interneto erdvei (inf.) - jų gausu elektroninių svetainių ir tinklaraščių straipsniuose. Tokie rezultatai nestebina: ankstesni viešosios rašytinès vartosenos, artimos interneto informacinès erdvès tekstams, tyrimai rodo, kad naujažodžio reikšmę aiškinantys $M K$, be išskirtinės grafikos, yra vienas pagrindinių naujažodžių integracijos ị tekstą elementų [žr. 6]. Komunikacinei interneto erdvei (kom.), apimančiai

(6) Naujažodžiai klasifikuojami įvairiai, pavyzdžiui, pagal radimosi kalboje būdą, naujo kalbos reiškinio tipą, pavadinamos realijos pobūdị, naujumo laipsnị, - nelygu tyrimo tikslas, pasirinktas teorinis pagrindas, tiriamosios medžiagos pobūdis ir pan. [plačiau žr. 24, 7-11; 35, 52; 8, 74-75]. Bene ịprasčiausia klasifikacija, bent jau lietuvių kalbotyrai, - pagal naujažodžio radimosi kalboje būdą. Ji parankiausia ir šiam darbui. Pirmiausia pagal ją naujažodžiai sutartinai skirstomi į du stambiausius leksinių naujovių tipus: naująsias leksemas ir naująsias sememas $[16,206 ; 24,7]$; nuo pastarųjų pasirinktasis darbo objektas leido atsiriboti, plg. naująja semema laikytiną aptariamus naujuosius darinius vienijantị elementą - daiktavardị tinklas (angl. network), skaitmeniniame amžiuje igavusị naują, interneto, reikšmę. Naujosios leksemos pagal radimosi kalboje būdą skiriamos ị savo kalbos išgalèmis pasidarytus naujuosius darinius ir pasiskolintus naujus žodžius - naujuosius skoliniu s $[29,28-29 ; 24,7 ; 28,97 ; 35,49 ; 6,79,7,75]$. Naujaisiais skoliniais straipsnyje laikomi ir žodžiai su skolintomis šaknimis bei lietuviškais darybos afiksais, kurie vertintini greičiau kaip prisitaikymo prie lietuvių kalbos gramatinès sistemos, o ne darybos priemonè, pvz.: bloginti, angl. to blog [plg. 19, $114 ; 25,70]$. Funkciniu požiuriu naujažodžius galima skirti ị dvi pagrindines grupes - nominatyvinius, paprastai einančius tam tikros srities terminais, ir stilistinius, pasitelkiamus kaip fakultatyviuosius, ekspresyvesnius sinonimus. Nominatyviniai, arba būtinieji, naujažodžiai įvardija naujas realijas, t. y. atlieka referentinę, kitaip - informacijos perdavimo, funkciją, o stilistiniai, arba fakultatyvieji, naujažodžiai $\mathfrak{t}$ tekstą įtraukiami stilistiniais sumetimais, čia svarbiausia emocinè ekspresinè funkcija [plg. 6]. 
diskusijų forumų, straipsnių komentarus ir pan., MK, kurių vienintelè funkcija - atskleisti naujažodžio reikšmę, palyginti su informacine erdve, nèra būdingi. Elektroninèje, kaip ir rašytinejje, vartosenoje paprastai aiškinama referentinę funkciją atliekančių nominatyvinių naujažodžių - naujųjų skolinių ir naujaisiais dariniais išreikštų jų lietuviškų atitikmenų, dažnai einančių kompiuterijos terminais, reikšmė [plg. 6]. Stilistinių naujažodžių, kuriems būdingesnè emocinè ekspresinė funkcija, reikšmė retai tekomentuojama.

1.1. Informacinejje interneto erdveje gana gausiai aptinkami metakalbiniai vienetai su socializacijos etapo dar nebaigusių naujųjų skolinių MK paprastai yra skirti naujam, adresatui greičiausiai nežinomam skolintam terminui vienaip ar kitaip paaiškinti: nurodoma originalo forma, pamatiniai žodžiai, jų reikšmé; mėginama išversti, apibūdinti skoliniu ivvardijamą realiją ir pan. - panašūs polinkiai būdingi ne tik viešajai rašytinei lietuvių, bet ir kitų kalbų vartosenai [plg. 13; 15; 6; 7]. Pavyzdžiui:

- Jūs gausite internetinị puslapị, kuris turès standartinio blogo (angl. Blog) išdèstymą ir dizainą [inf. 2007].

- Interneto svetainès autorius Jornas Bargeris pavadino savo tinklalapi „weblogu“. Tai dviejų angliškų žodžių junginys: „web“ (angl. tinklas) ir „log“ (angl. „logging“ - kompiuterio programos atliekamų veiksmų sekos dokumentavimas) [inf. 2008].

- Podcast - tai naujas žodis, sudètas iš dviejų - iPod ir broadcast [inf. 2007].

- Vienas „blogeris“ (dienoraščių rašytojas) ... gavo akreditaciją ị Baltuosius rūmus [inf. 2005].

- Turès galimybę: gauti prisijungimą prie Eurodesk intraneto (vidinio tinklo) ir duomenų bazių [inf. 2011] (7).

Tokie metakalbiniai vienetai, kaip ir kitose kalbose, atlieka metakalbinę funkciją - ji dažniausiai atsiskleidžia teksto kūrejjo paaiškinimuose skaitytojui, kai autorius jaučia, kad jo pristatoma realija yra nauja ir daugeliui nepažistama [12, 249]. Kaip matyti iš pateiktų iliustracinių pavyzdžių, metakalbinę informaciją tokiais atvejais labiausiai linkstama pateikti skliaustuose arba kaip atskirą sakinio ar teksto fragmentą.

Pažymėtina, kad informacinei interneto erdvei būdingesni naujojo skolinio reikšmę aiškinantys MK, kuriuose pateikiama žinių apie pati skolintą naujažodị - originalo forma, (pamatinių) žodžių reikšmė ir pan. Pastebėtina, kad čia, kaip ir viešojoje rašytinejje vartosenoje, po skolinio aiškumo sumetimais pateikiamas jo vertimas, lietuviškas skoliniu îvardijamos realijos apibūdinimas (šiuo atveju dienoraščio rašytojas, vidinis tinklas) gali būti interpretuojamas kaip savotiškas skolinio atitikmuo [plg. 7, 98-99], galintis suteikti pirminị impulsą skolinto ir lietuviško tos pačios realijos pavadinimo konkurencijai. Vis dèlto skolinio vertimas panašios reikšmès savos kalbos žodžiu ar esamų žodžių junginiu dažniausiai

(7) Čia ir toliau pavyzdžiuose aktualūs teksto elementai retintu šriftu yra išskirti straipsnio autorès, kalbinè raiška palikta autentiška, praleistos teksto vietos žymimos iš abiejų pusių tarpais išskirtu daugtaškiu (pakeistos tik nelietuviškos kabutès ir kaip skyrybos ženklai naudoti trumpieji brūkšniai). 
neperteikia tikrosios skolinio reikšmės, jų semantinè apimtis skiriasi - tai pastebi ir kitų kalbų tyrèjai [plg. 15]. Taigi tokie pirminiai aprašomojo, verstinio pobūdžio realijos apibūdinimai, atliekantys metakalbinę funkciją, nors formaliai ir galimi interpretuoti kaip savotiški skolinio atitikmenys, retai tampa realiais jo konkurentais, t. y. retai kada gali ilgainiui atlikti referentinę funkciją. Tai liudija ne tik šis ir kiti minèti dabartiniai ịvairių kalbų tyrimai, bet ir gerokai senesnès lietuviškos viešosios rašytinės vartosenos analizės rezultatai. Nustatyta, kad XX a. 3-4 dešimtmečių Rytprūsių lietuvių spaudoje tik itin retais atvejais „vertinys pradedamas vartoti savarankiškai“ $[4,187]$.

Semantinė leksikos variantų apimtis yra adekvatesnè tais atvejais, kai tam pačiam lizdui priklausančio skolinio dariniai (blogas - blogosfera) yra komentuojami žodžių junginiu, kurio vienas dèmuo - jau seniau atsiradęs ir vartosenoje kaip tinkamas pamatinio skolinio atitikmuo prigijęs naujadaras (blogas - tinklaraštis), pavyzdžiui:

- Blogosfera, arba tinklaraščių visuma, jau tapo ịprastu dalyku. Štai, kad ir dabar, skaitydami šị straipsnị, esate blogosferos dalyvis, o jei dar ir parašysite komentarą [inf. 2008].

Tokiais atvejais kaip MK gali būti pasitelktas ne tik žodžių junginys, bet ir iš esamo atitikmens pasidarytas naujasis darinys, t. y. skolinio semantinę apimtį visiškai atitinkantis atitikmuo (blogeris - tinklaraštininkas), pavyzdžiui:

- Tinklaraščiams priskiriamos specializuotos interneto svetainès ... kuriose talpinamos dažnai rašomos publikacijos, išdèstytos chronologine tvarka, kuriose autoriai, vadinamieji „blogeriai“ (tinklaraštininkai), išsako savo mintis, ịvykius, pastebejjimus ir idejjas pasirinkta tema [inf. 2007].

Komunikacinèje interneto erdvejje, kuriai, palyginti su informacine, naujojo skolinio reikšmę aiškinantys MK nebūdingi, matomesni būtent tie atvejai, kai savotišku MK eina naujadaru išreikštas skolinio atitikmuo, pvz.:

- Blogeris (tinklaraštininkas) yra tas, kuris rašo blogą (tinklaraštị). Jei jo net neturi, logiška, kad negali vadintis blogeriu [kom. 2008].

Tokių atvejų, kai tapačios semantinès apimties naujuoju dariniu išreikštas naujojo skolinio atitikmuo internete vartojamas metakalbiniais sumetimais, yra nemažai, taigi galima kalbèti ne tik apie komunikacinei, bet ir informacinei interneto erdvei (ypač laisvesnei - asmeninių tinklaraščių straipsniams, pvz.: turintiems savo ... blogus (tinklaraščius) ir nors kiek besidomintiems SEO pateiksiu ... SEO įskiepius bei trumpus jų aprašymus [inf. 2010]), palyginti su viešąja rašytine vartosena, būdingą polinkị kalbos vartotojams jau žinomus atitikmenis pateikti kaip metakalbinius skolinių komentarus. Vis dèlto pažymètina, kad tokie komunikacinèje ir informacinèje interneto erdvèje aptinkami metakalbiniai vienetai su skolinių atitikmenimis, kurie tam tikrame pasakyme pateikiami kaip šalutiniai, metakalbiniai, teksto elementai, paprastai esti metakalbinių vienetų bloko, apimančio įvairios paskirties MK, didesnio naujažodžių diskurso elementai (plačiau žr. 3-ią skyrių).

Šalia referentinę funkciją atliekančių naujųjų skolinių aiškinamaisiais sumetimais pateikiami paaiškinimai ar lietuviški atitikmenys kartu su komentuojamąja teksto vieta atlieka 
metakalbinę funkciją [plg. 30]. Tačiau bent jau naujaisiais dariniais išreikštų naujojo skolinio semantinę apimtị atitinkančių atitikmenų atveju metalingvistinè funkcija laikytina papildoma - iš esmès jie, kaip ir jų pirmtakai skoliniai, yra atsiradę kaip referentinę funkciją turintys atlikti naujažodžiai, kurie ilgainiui gali nukonkuruoti skolintą variantą, pasikeisti su juo vietomis, t. y. skolinys imamas vartoti metakalbiniais sumetimais kaip fakultatyvus, aiškinamasis, teksto elementas (žr. 1.2 poskyrị). Tai būdinga ir ankstesnei, ikiinternetinei, ir dabartinei, tarp jų ir internetinei, viešajai rašytinei vartosenai [plg. 7]. Tik internetinei vartosenai, ypač laisvesnei komunikacinei ir informacinès daliai - tinklaraščių straipsniams, būdinga, kad tie patys metalingvistinę funkciją atlikę naujaisiais dariniais išreikšti atitikmenys kitoje frazejje gali būti vartojami kaip referentinę funkciją atliekantys teksto elementai (plačiau žr. 1.3 poskyrị).

1.2. Informacinei interneto erdvei būdingi ne tik aprašytieji $M K$, aiškinantys socializacijos etapo dar nespejusius baigti naujuosius skolinius. MK labai dažnai palydimi ir vartosenoje dar nespeję ịsitvirtinti naujieji dariniai, ppr. einantys naujųjų skolinių atitikmenimis, tai yra nominatyviniai naujažodžiai, kurių pagrindinè funkcija yra referentinè. Kaip ir viešojoje rašytinejje vartosenoje [žr. 6; 7], pragmatiniais sumetimais jie dažniausiai aiškinami adresatui ịprastais skoliniais (arba neadaptuota originalia jų forma, ppr. nurodant kalbą, raidine santrumpa), pavyzdžiui:

- Naudojimasis internetu ... suprantamas kaip bendruomenès tinklinimasis (angl. „networking“) [inf. 2005].

- Tinklintojai (angl. network users) savo bendrų rato nesuvokia kaip sektos [inf. 2007].

- Laimètojų tarpe yra ir Tinklalapyno (WWW) išradejjas Tim Berners-Lee [inf. 2008].

- Iki šiol tarp ... tinklinukų (netbook) buvo tik itin lengvi ir ploni ... nešiojami kompiuteriai [inf. 2011].

- Tinklaraščiai (arba liaudiškai dar vadinami blogais) turi ir gerų, ir blogų savybių, ir dar neaišku, kurios iš jų taps pranašesnès laikui bėgant, kaip ir neaiški tinklaraščių ateitis [inf. 2008].

- Tinklaraštininkas, arba kitaip vadinamas blogeris, iš Lietuvos ... yra tarp ịtakingiausių [inf. 2008].

- Visi tinklaraščiai sudaro vadinamąją tinklaraštiją (blogosferą) [inf. 2012].

- Tai socialinių ryšių mikrotinklaraštis (angl. - microblogging), suteikiantis lankytojams galimybę skelbti trumpąsias žinutes tinklalapyje [inf. 2008].

- $\quad$ Kaip pradèti tinklaraščiu oti, t. y. bloginti? ... blogo kūrimų svetainès - www.blogas.lt [inf. 2010]. 
- Projektas tęsiasi, tačiau visai „nuvytęs“ nuotraukų publikavimas ir tinklar aščiavi mas (... anksčiau tai vadinosi bloginimas - aut. pastaba) [inf. 2010].

- Vykdo ... vidinio tinklyno (intraneto) priežiūrą, informacijos sisteminimą, skelbimą bei atnaujinimą [inf. 2010].

- Potinklis (subnet) faktiškai yra vienas tinklo kabelis [inf. 2010].

- C Čia rasite ištisą madai skirtų tinklalaidžių (arba podkastų) ciklą [inf. 2012].

- RSS yra XML failų formatų šeima ... duomenų rinkimui išn na ujientinklių (angl. news websites) [inf. 2012].

Pasitaiko atvejų, kai naujuoju dariniu išreikštas skolinio atitikmuo aiškinamas ne skoliniu, bet kitu seniau pasiūlytu ir kalbos vartotojams jau pažistamu atitikmeniu, pvz.:

- Girdime diskutuojant apie Web 3.0, dar žinomą trečiosios kartos saityno (žiniatinklio) pavadinimu [inf. 2012].

Kaip matyti iš pateiktų iliustracinių pavyzdžių, naujaisiais dariniais išreikštų atitikmenų reikšmę aiškinantys tipiški MK, kurių pagrindas - anksčiau ị vartoseną patekę tą pačią realiją îvardijantys skoliniai ar, retai, seniau pasiūlyti atitikmenys, taip pat dažniausiai pateikiami skliaustuose, rečiau - po jungtuko arba, t. y. ir pan. Taigi, kaip rodytų pateikti vartosenos pavyzdžiai, referentinę funkciją atlikdavę naujieji skoliniai (žr. 1.1 poskyrį), igiję vartotojų lūkesčius atitinkančių, konkuruoti gebančių lietuviškų atitikmenų, kurị laiką gali būti vartojami kaip pastarųų palydovai, atlikti metakalbinę, aiškinamąją, funkciją - tai būdinga ir ankstesnei, ikiinternetinei, rašytinei viešajai vartosenai [plg. 9, 147]. Žinoma, metakalbinę funkciją tokiais atvejais atlieka ne vieni skoliniai, bet visa frazè, su kuria jie vartojami [12, 249].

Komunikacinei interneto erdvei, palyginti su aprašytąja informacine, naujaisiais dariniais išreikštų atitikmenų, kaip ir anksčiau minètų jų konkurentų naujųjų skolinių, reikšmę aiškinantys MK nebūdingi. Bet čia galima rasti metakalbinių vienetų, liudijančių tokių skoliniais išreikštų MK poreikị arba perteklių (juos galima priskirti naujažodžių vertès aiškinamiesiems), pvz.:

- Apie tinklaraštininkus (blogerius). Ar reikia skliausteliuose patikslinimo?

- Ana: Be abejo, reikia [t. y. tinklaraštininkus (blogerius)]. Gi tuos terminus vis naujus išgalvojate, negi žmonès turi kažkur ieškoti pirmojo paminejjimo, kad sužinotų, ką tas žodis reiškia? Ypač jei vertimas neintuityvus.

- Anai: Noréčiau priminti, kad žodị tinklaraštininkas vienoje diskusijoje pasiūlè visai ne kalbininkas (nes pats po to gynèsi juo nesąs), o vlkk tik pateikè balsuoti, surinkusi visus pasiūlymus. Mes, šios svetainès lankytojai, patys balsavome už šitą, o ne kitą žodị. Čia kaip po rinkimų - pirma išsirenkam, po to kritikuojam. Bet su vienu dalyku sutinku, mieloji Ana, kol visuotinai nepripažintas (vlkk, kiek žinau, jo dar net nesvarstė), reikia vartoti abu. 
- Patirtis: Raginu pamąstyti: ar apskritai mums visiems reikia prie „diegiamų“ lietuviškų atitikmenų prirašyti svetimžodžius (su kabutėmis arba skliausteliuose)? ... Na, vieną kartą pavartoti gal ir reikia, bet, manau, toliau nederètų minèti ... [kom. 2008].

1.3. Metakalbinius vienetus su 1.1 ir 1.2 poskyriuose aptartais vienas kitą aiškinančiais, tą pačią realiją îvardijančiais skolintais ir savakilmiais naujažodžiais išreikštais pavadinimais (pvz.: blogeris (tinklaraštininkas) / tinklaraštininkas (blogeris)) galima vertinti kaip ivvairiakalbiams tekstams būdingą autorių pasirinktą interakcijos strategiją (8) [plg. 2; 4]. Tokie naujaisiais dariniais einančių skolinių atitikmenų, kaip ir anksčiau aprašyti naujųjų skolinių, reikšmę aiškinantys MK interpretuotini kaip tradicinė naujažodžių integracijos i tekstą priemonè - panašiai kaip viešojoje rašytinejje vartosenoje [plg. 6]. Vis dèlto matyti ir akivaizdžių skirtumų: komunikacinei, o ir laisvesnei informacinei interneto erdvei, ypač tinklaraščių straipsniams, būdinga itin variantiška konkuruojančių skolintų ir savakilmių naujažodžių - naujụjų skolinių ir naujaisiais dariniais išreikštų jų atitikmenų - vartosena su įvairios paskirties MK intarpais, pvz.:

- Blogas apie tinklaraščius. BLOGAS, DIENORAŠTIS, TINKLARAŠTIS, ŽURNALAS ... Tiek daug vardų tam vienam asmeninès raštliavos puslapéliui. Tuo ir graži lietuvių kalba, nes vienam dalykui yra tiek daug apibūdinimų. Pasistengsiu pateisinti visų šių vardų funkcijas ir niuansus. Blogas apie tinklaraščius yra asmenine iniciatyva apie Lietuvos ir pasaulio blogus ir blogosferą. Nagrinëjami ịvairūs su tinklaraščiais susiję klausimai, aprašinejjami blogai, sudarinėjami tam tikrų sričių tinklaraščių TOP [inf. (tinklaraščio straipsnis) 2010].

Palyginti su viešąa rašytine vartosena, kur paprastai kaip pagrindinis tos pačios realijos pavadinimas pasirenkamas ir tekste nuosekliai vartojamas vienas iš leksikos konkurentų, dažniausiai lietuviškas, o skolinys pasitelkiamas tik kaip fakultatyvus, aiškinamasis, metakalbinę funkciją atliekantis teksto elementas (pirmąkart pavartojus realijos pavadinimą [žr. 6;7;9]), tokią interneto erdvei būdingą naujažodžių sinonimiją, kai tame pačiame tekste metakalbiniais sumetimais pavartotas naujažodis toliau, pramaišiui su komentuojamuoju, atlieka ir referentinę funkciją, galima vertinti kaip išskirtinai internetinei, ypač - laisvesnei, vartosenai būdingą polinkị. Tai patvirtina ir metakalbiniai naujažodžių vertès aiškinamieji komentarai, pvz:

- Kaip dèl rašymo stiliaus? Kai [atsisakius blogo - J. G.] kiekviename sakinyje kartotųsi žodis „tinklaraštis“? [kom. 2009].

- Aš naudoju vieną šalia kito, bet tinklaraštis atrodo šiek tiek gražiau. ... Taigi, gaunas taip, kad „blogeris rašo tinklaraštị“. Skamba visai gražiai:) [kom. 2009].

- Nieko blogo tas blog’as. Nors ... aš naudoju dažniausiai žodị tinklaraštis [kom. 2009].

(8) Toks sąvokos pateikimo būdas, kai tekste greta skolinto žodžio vartojamas ir jo atitikmuo besiskolinančioje kalboje - vertinys ar senas tos kalbos žodis [2; cituojama iš 4,181$]$. 


\section{NAUJAŽODŽIO VERTĘ APTARIANTYS MK}

Metakalbinè funkcija atsiskleidžia ne tik tada, kai teksto autorius, jausdamas realiją esant naują ir skaitytojui nepažistamą, MK aiškina ją ịvardijančio naujažodžio reikšmę, bet ir tada, kai svarsto, kaip žodis tinka sąvokai įvardyti [12, 249]. Naujažodžio vertę, kartu dažnai ir jo santykius su tą pačią realiją ịvardijančiais leksikos konkurentais, aptariantys MK, kitaip nei aprašytieji informacinei terpei būdingi reikšmės aiškinamieji, daug dažniau aptinkami komunikacinèje interneto erdvejje - jų gausu diskusijų forumuose, straipsnių komentaruose ir kt.

Kaip ir reikšmès aiškinamųjų, taip ir vertès nusakomųjų MK labai retai sulaukia emocinę ekspresinę funkciją atliekantys neformaliai erdvei šiaip jau būdingi vadinamieji fakultatyvieji, stilistiniai, naujažodžiai (b), pavyzdžiui:

- $\quad$ a) Mano blogui, t. y. tinklaraščiui, o gal labiau asmenraščiui ar durnaraščiui, kaip pavadinsi - taip, šiandien lygiai 4 metai ... [inf. (tinklaraščio straipsnis) 2011].

- $\quad$ b) Su tinkladieniu:) [kom. 2011].

Va, koks tas teisingas žodis!:) ačiū [kom. 2011].

Kaip matyti iš pateiktojo iliustracinio pavyzdžio ịvadinès, kontekstinès dalies (a), stilistiniai naujadarai (pabrauktas) neretai patys tampa MK dalimi (apie tai dar žr. 3.2 poskyrị).

Vertinamaisiais MK paprastai palydimi nominatyviniai naujažodžiai - būtinų ịvardyti realijų pavadinimai, kurių pagrindinè funkcija referentinè. Vertès komentuojamieji MK itin būdingi naujaisiais dariniais išreikštiems naujųjų skolinių atitikmenims, bet tokių komentarų sulaukia ir jų konkurentai - naujieji skoliniai.

Vertinamuosius naujažodžių, kaip ir kitus, MK galima skirti ị dvi pagrindines grupes - teigiamo ir neigiamo vertinimo [plg. 21, 55]. Anot etnolingvistikos specialistų, „neigiamas vertinimas kalboje išreikštas dažniau negu teigiamas“, - šią asimetriją patvirtina visi aksiologiniai tyrimai: greičiausiai ji yra universali ir remiasi pragmatišku pasaulio suvokimu - tai, kas gera, priimama kaip norma, o kas negera, laikoma nukrypimu nuo jos ir todèl labiau pastebima [14, 130-131]. Ankstesni MK tyrimai rodytų, kad šis dėsningumas galioja ir kalbos reiškinių aksiologijoje (9). Vis dèlto pastebima, kad kalbos vartotojai nevengia pabrèžti ir teigiamo kalbos vertinimo [plg. 21, 55]. Tai būdinga ir ịvairiatipiams naujažodžiams: ir naujieji skoliniai, ir kaip jų atitikmenys pasiūlyti naujieji dariniai sulaukia ir neigiamų, ir teigiamų vertinimų.

2.1. Komunikacinèje interneto erdvèje aptinkamuose teigiamo vertinimo MK pabrèžiamas naujaisiais dariniais išreikštų skolinių atitikmenų lietuviškumas; kokybiškumas, tinkamumas sąvokai ịvardyti: aiški darybos motyvacija, skoliniui analogiška semantinè apimtis, sistemiškumas - analogija su kitais tinkl- elementą turinčiais dariniais, darybos tipiškumas, ekonomiškumas; estetiškumas: skambumas, gražumas; paplitimas vartosenoje, pvz.:

- Dar, rodos, buvo ir trumpesnis variantas [nei interneto dienoraštis] - tinklaraštis [kom. 2005].

(9) Neigiamo vertinimo polinkiai minimi ir ankstesnių (iki $2005 \mathrm{~m}$. imtinai) internetinių komentarų, susijusių su kalba, apžvalgoje [22, 4]. 
- Tinklaraštis yra raštas tinkle, o jị rašo žmogus, esantis tinkle. Žmogus rašantis tinkle yra tinklaraštininkas. Iš lietuvių verčiam ị anglų: tinklaraštininkas = bloger [kom. 2007].

- Web log iš anglu - tinklo raštas, taigi tinklaraštis. Parduotuveje dirba pardavejjai, kirpykloje kerpa kirpejjai, o tinklaraštị rašo tinklaraštininkai [kom. 2008].

- Lengvai išsisprendžia problema blogger - tinklaraštininkas, blogosphere - tinklaraščiai [kom. 2008].

- Tai [oficialiai] dar nenusprendè? Juk visa media jau naudoja tinklarastininkas [kom. 2008].

- Aš už tinklaraštis, tinklaraščio autorius, tinklaraštininkas. Gražu, lietuviška, skambu [kom. 2009].

- Aš už. Anksčiau kai LT buvo Tarybų sąjungos dalis, daug žodžių naujai sužinotiems ar išrastiems dalykams peremė iš rusų kalbos. Dabar atseit persivertę ị vakarų kultūros siekejus žodžius skolinamės iš anglų. Kaip sakant, „,anksčiau rusenom, dabar anglejjam“. Lietuvybè ir naujadarai nèra blogai. Jie stiprina kalbą ir kultūrinị identitetą. Taigi jamam tą „tinklaraštị “ ir „tinklaraštininką“ [kom. 2009].

- Tinklaraštis yra labai gražus ir normalus lietuviškas žodis, kuris nors ir neitteisintas, vis dažniau naudojamas. ... Be to, jei kliūva tinklaraštis, tai turètų kliūti ir tinklalapis, kodèl visi masiškai nerašo websaitas? [kom. 2009].

- Tinklavietè - labai geras žodis, lietuviškas ... ankstesnis žodis - svetainè - buvo paremtas polisemija, todèl aiškumo sumetimais reikèdavo pridèti inter ne to svetainè, o tai jau nelietuviškas žodis, ... tinklavietę sudaro atskiri tinklalapiai, puiku [kom. 2007].

- Tinklavietė normalus sudurtinis žodis - piliavieté, ... turgavieté, vasarvieté, kirtavietė [kom. 2007].

- Ateityje „nikneimą“ stengsiuosi keisti ị [lietuvišką] „tinklavardis“ [kom. 2008] .

- Tiek žiniatinklis, tiek tinklalapis lietuviškai puikiai skamba [kom. 2009].

- $\quad$ Sveikinu visus su gimusiu daug parankesniu žodžiu: Žiniatinklis persikrikštijo i̇ SAIT Y NĄ. Žr.: http://www.vlkk.lt/lit/88519 [kom. 2009].

- O man labai gražu saitynas ir mano įstaigoje mes ji jau pradedam vartoti:) [kom. 2009].

- Sąmoningai neịsijungiau ị diskusiją, norèjau leisti naujadarui [saitynas] ramiai manyje pagyventi, kad pažiūrečiau, ar susigyvensime. Dabar sakau: Tai LABAI VYKĘS, LAIKE SUBRENDĘS NAUJADARAS. Be abejo, jis turi savo AUTORIŲ, kažkas pirmas pasakè: eureka [kom. 2009]. 
- Dūzgès gali ir neprigyti, o va tinklinukas visai geras [netbuko] pakaitalas [kom. 2011].

- Tinklavardis yra „nick’as“. Manau tas aišku ... Gyvenu Lietuvoje, kalbu lietuviškai ir reiškiu savo mintis lietuviškai ... Tinklaraštis, tinklavardis tai normalios, suprantamos sąvokos [kom. 2012] (10).

Komunikacinejje interneto erdvejje aptinkamuose neigiamo vertinimo MK, atvirkščiai, nurodomas atitikmenimis einančių naujųjų darinių estetikos trūkumas - gremėzdiškumas ir pan.; svarstomas kokybiškumas, tinkamumas sąvokai įvardyti: ekonomiškumo trūkumas, neaiški darybos motyvacija, nesistemiškumas, skoliniui neadekvati semantinè apimtis, perteklinė lietuviškų variantų sinonimija, pvz.:

- Kompiuterị, skirtą naršyti internete, anglų kalba vadinamą „netbook“ keičia žodis „tinklinukas“... Tinklinukas ir kavavirys neįsispraudžią gremėzdai [kom. 2009].

- Dūzgès geras žodis ir tikriausiai prigis, o tinklinukas - ne [kom. 2011].

- Va „tinklaraštininkas“ jau nekas - pirmiausia dèl to, kad labai ilgas ir nepatogus ištarti. Nebent trumpintume ji iki „tinklarašio“. Rašantis tinklarašti - tinklarašys [kom. 2009].

- VLKK siūlo: „Galimi žodžio „blogas“ pakaitai: interneto (ne internetinis) dienoraštis, tinklaraštis, asmenraštis ar kt.“ Internetinis dienoraštis dar dar (nors ir ilgokas), tačiau asmenraštis, kad ir apibūdina kas yra „blog“, kitą vertus nenusako pilnai, jog tinklaraštis egzistuoja internete ..., taip pat ... sudaro prielaidą nuomonei, jog asmen raštis - kažkas asmeniško ir konfidencialaus, tuo tarpu tinklaraščiai nukreipti ị sociumą [kom. 2009].

- O tai yra viešai ir oficialiai patvirtinta, kad blogas yra tinklaraštis? Nes jei taip, tai blogerio pavadinimas taip pat turi būti susijęs su tinklaraščiu. Negi bus mintrašys, po to patị bloginimą kaip procesą pavadinsim dienoraštinimu ir pan. [kom. 2008].

- „Siuntinukas“VS podcast'ai. Manau ... neatitinka esmès, tai visų pirma radijo laida, o ne medžiaga persiuntimui [kom. 2008].

- „Saitynas“ gal ir neblogas, bet neužmirškim, kad jau kurị laiką gyvavo „žiniatinklis“ ir su tuo terminu pasirodè ne vienas žodynèlis, straipsnis ir knyga, jau nekalbant apie internetą. Ivvedus naują terminą vèl kuriama painiava, pavyzdžiui aš nežinau kaip elgtis oficialioje komunikacijoje. Jei pavartosiu „saitynas“, daugeliui tai bus naujas terminas ir galiu likti nesuprastas, jei vartosiu „žiniatinklis“, VLKK požiūriu naudosiu neteisingą terminą. Todèl esu ne prieš terminą, o prieš kuriamą painiavą, kuri apsunkina komunikaciją [kom. 2009].

- Saitynas per daug primena anglišką tos srities terminą „site“ ... Žodyje „saitynas“ visas dėmesys atrodo skirtas ryšiams, o mazgai, saistomi objektai tarytum pamiršti (visai priešingai, nei angl. „sites“) [kom. 2010].

(10) Metakalbinių vienetų su ilgateksčiais naujažodžių vertinamaisiais $\mathrm{MK}$, vengiant galimo blaškomo išskirtinès grafikos poveikio, paprastai išskiriami tik aktualūs naujažodžiai. 
MK, nusakančių naujaisiais dariniais išreikštų atitikmenų vertę, pasitaiko ir informacinèje erdvèje, kaip ir jai giminingesnèje viešojoje rašytinejje vartosenoje [6;7], pavyzdžiui:

- Internautų (kalbininkai siūlo keisti „tinklininkais“ arba - kiek rimčiau „tinklažmo giais“) Lietuvoje dar nedaug, bet neišvengiamai ir negrižtamai daugeja, tad, žinoma, gausejja internetinès žiniasklaidos skaitytojų ir didejja tokios žiniasklaidos svoris, o ir ji pati tvirtėja [inf. 2003].

- Iš esmès sklandų Patricijos Droblytės teksto vertimą apsunkina naujų sąvokų „tinkla veika“ ir „tinklaveikos visuomenë“ ivedimas ị lietuvių kalbą. Knygoje nepaaiškinama šios lietuviškos sąvokos kilmè ir prasmé, tačiau sekant M. Castellso vartojama „network society“ sąvoka kyla ịtarimas, jog žodžiui „network“, paprastai suprantamam kaip „tinklas“, „tinklai“, priklijuojama griozdiška pažodinio vertimo sąlygota reikšmé, susijusi su tinklo „veikimu“. Šitaip visiems suvokiama „tinklo visuomenë“ tampa mistišku „tinklaveikos visuomenès“ dariniu [inf. 2005].

- Atvirai pasakysiu, pats žodis tinklaraštis, nors jo vengiu, man gražus [inf. (tinklaraščio straipsnis) 2007].

- Tegalime guostis, kad net ir patys keisčiausi žodžiai, ėmę gyventi, sparčiai kitèja ir įprastejja: juk nedaug trūko, kad šiandieninis „tolimatis“ reikštų ne tik matavimo įrankį, bet ir, kaip siūlè tarpukario Lietuvos Respublikos kalbininkai, televizorių; jau pripratome ir prie „žiniasklaidos“, tad gal priprasime ir prie „žiniatinklio“ [inf. 2009].

- Kad ir žodis žiniatinklis (angl. Web). Juk jau seniai internetas tapo ne tik žinių šaltiniu, bet ir atskira verslo ar pramogų šaka [inf. (tinklaraščio straipsnis) 2010].

Iš pateiktų pavyzdžių matyti, kad, kaip ir komunikacinėje erdveje, čia esama ir teigiamo, ir neigiamo naujųjų darinių vertinimo: panašiai kaip ir komunikacinejje terpejje, vertinamas naujadaro (ne)estetiškumas, (ne)tinkamumas sąvokai ịvardyti, neịprastumas ir kt. Vis dèlto pabrěžtina, kad naujuosius darinius vertinantys MK informacinei terpei nėra tokie būdingi kaip komunikacinei interneto erdvei.

2.2. Komunikacinèje interneto erdvèje komentuojama ir naujųjų skolinių vertè. Teigiamo vertinimo MK diskutuojamas grynumo kriterijus, t. y. nelietuviškumas, kaip vienintelis skolinio keitimą lemiantis veiksnys; vertinamas skolinto žodžio estetiškumas - skambumas ir kt.; kokybiškumas, tinkamumas sąvokai ịvardyti: ekonomiškumas, sistemiškumas (pvz., analogija su kitais blog- elementą turinčiais skoliniais); iprastumas ir su tuo susijęs suprantamumas, pvz.:

- Man pačiam labai gerai skamba podkastinimas [kom. 2005].

- Bet manau visiems bus lengviau suprasti, jeigu vadinsime ir toliau Blog'ais [kom. 2008]. 
- Tik tas tinklaraštininkas labai jau gremèzdiškai skamba, blogeris daug smagiau [kom. 2008].

- Tačiau vienas žodis, kuris nevartotinas tik todèl, kad nèra lietuviškas, man neatrodo kaip didelè problema ... aš kažkaip nelinkęs visiškai atsisakyti blogo [kom. 2009].

- Kuo blogas jums neįtiko? nèra pats geriausias žodis LT kalboje, bet man patinka, kad jis blogas;) tinklaraštis pernelyg ilgas žodis - nepatogu [kom. 2009].

- Taciau kartais tas „blogas“ neblogai skamba [kom. 2009].

Komunikacinejje interneto erdvejje aptinkamuose neigiamo vertinimo MK, atvirkščiai, dažniausiai reiškiamas nepasitenkinimas skolinių nelietuviškumu, rečiau - nepatogumu; nurodomas jų estetikos trūkumas; svarstomas kokybiškumas, tinkamumas sąvokai ịvardyti - nemokantiems angliškai neaiški darybos motyvacija, homoformiškumas su savu žodžiu, pvz.:

- Bèda ta, kad mes jau turime žodi „blogas (blogis)“ visai kita reikšme - todèl reikia naujo žodžio [kom. 2005].

- Visų pirmą pakeiskite Blogą kitu žodžiu. Lietuvių kalboje „Blog as“ turi savo reikšmę ir ji neigiama. Klausimas kyla, kaip galima šnekèti apie Blogą teigiamai? Iš tikro pykina tas neišverstas naujadaras - parazitas [kom. 2007].

- Mano mintis buvo „blogas blogas yra blogas“.... kai pasakoji apie tai pirmą kartą girdinčiam žmogui, tai beveik kiekvienas paklausia „O kas tas blog as?“. Tada tenka aiškinti, kad blogas, tai internetinis dienoraštis arba kažkas panašaus. O tada būna kitas klausimas „O tai kodèl jis blogas?" Atvirai pasakius - užknisa ... [kom. 2009].

- Žmonès galvoja, kad aš kažkoks VLKK pakalikas, kai realiai man tiesiog žodžio „blogas" skambesys sakiniuose yra baisus [kom. 2009].

- $\quad$ Aš versdamas pagalvoju, kokị variantą suprastų žmogus, kuris nemoka angliškai, tai tokiu atveju „podcast“ nelabai aišku būtų, "garso prenumerata“ - bent jau pasiūlytų mintị, apie ką šitas dalykas [kom. 2011].

- $\quad$ Reikètų kalbininkams pagalvoti apie podcast atitikmeni [kom. 2012].

Informacinejje interneto erdvèje, paprastai laisvesnèje - tinklaraščių straipsniuose, taip pat aptinkama naujųjų skolinių vertę nusakančių $\mathrm{MK}$ - ir teigiamų, ir neigiamų, pvz.:

- Reiktų paskelbt akciją „Pats tu blogas - aš rašau tinklaraštị!“ skirtą žodžiui „blog’a s“ atsikratyti [inf. (tinklaraščio straipsnis) 2009]. 
- $\quad$ Kaip jau pastebèjo kiti kolegos, RIMTOS FIRMOS BLOGAS skamba kvailokokai [inf. (tinklaraščio straipsnis) 2009].

Tačiau naujuosius skolinius, kaip ir naujuosius darinius, vertinantys MK informacinei interneto erdvei, palyginti su komunikacine, nebūdingi.

\section{METAKALBINIŲ VIENETŲ BLOKAI SU NAUJAŽODŽIŲ REIKŠMĘ IR VERTĘ NUSAKANČIAIS MK}

Pažymėtina, kad internetiniam naujažodžių diskursui būdingi metakalbinių vienetų blokai, kuriuose kalbos vartotojai ir aiškina(si) naujo žodžio reikšmę, ir nusako jo vertę (išskirta kursyvu), pvz.:

- Daug žmonių ... klausinèja ... kaip kurti blogą? ... Paklausęs draugo, ar žino kas tai blog'as, jisai net neabejodamas atsake, kad tai - „negeras“. ... Dar labai daug žmonių nenutuokia, kas tie blog'ai išvis yra! Blog'as - tai sulietuvintas angliškas žodis Blog. Blog'ai lietuvių kalboje vadinami tinklaraščiais. Bet manau visiems bus lengviau suprasti, jeigu vadinsime ir toliau Blog'ais. Blog'o kūrimas yra visiškai nemokamas, ir Blog'ą gali sukurti kiekvienas, kas perskaitys šį straipsnį, be jokių papildomų žinių ... Diskutuoti galima visur, kur papuola: kavinèje su draugais, internete. Bet įdomiau tai padaryti nuosavame Blog'e. ... Štai ir viskas ... Jūs turite Blog'o (tinkla raščio) pamatus [inf. (tinklaraščio straipsnis) 2008].

- Valstybinė Lietuvių Kalbos Komisija savo tinklapio antraštiniame puslapyje paskelbė apklausą: „Kuris termino angl. „blogger“ liet. atitikmuo geriausias?“ Galimi atsakymo variantai: mintrašys (nuo mintraštis), mintininkas (nuo mintynas), asmenraštininkas (nuo asmenraštis), tinklaraštininkas (nuo tinklaraštis), dienoraštininkas (nuo dienoraštis), dienoraščų rašytojas, dienrašys ... Kadangi angliškas terminas „,blog “ $($ web $+\log )$ apima ne tik internetinius dienoraščius, trys paskutiniai variantai atkrenta. Pirma karta gyvenime matau žodị "mintynas"(kaip kandynas) ir „mintraštis“ (kaip laikraštis) ... bet kuriuo atveju, „blogger“verčiu kaip „tinklaraščio autorius" ir neabejoju jo tikslumu - liežuvis neapsiverstu, pavyzdžiui, knygos autoriaus vadinti knygininku vien dèl to, kad taip trumpiau. "Asmenraštis“, beje, visai neblogai skamba [kom. 2008].

Naujažodžio reikšmės aiškinimas, palyginti su formalesne informacine interneto erdve - elektroninėmis svetainèmis, kur tai yra daroma siekiant padèti adresatui dekoduoti tekstą, integruoti i ji naujažodị, dažnai nèra savitikslis, ypač aktyviausiai naujažodžių diskursą plètojančioje komunikacinėje erdvėje. Reikšmès aiškinamieji MK (iškirti retintu šriftu) paprastai esti tarsi savotiška preliudija vertės aptariamiesiems, pvz.:

- $\quad$ Vargu ar yra prasmé pasaulinį tinklą siaurinti ar skaidyti pagal jo turinị. Tada reiks ir „paskalatinklio“, „plepatinklio“, „pornotinklio“ ir t. t. ir t. t. Galiausiai pasaulinio tinklo esmé yra jo globalumas, o ne iš to kylantys panaudojimai. Gal kada ir bus prasmè „tauškatinkliams“, bet kol kas jie visai nereikalingi. Tą WWW turinio detalizavimą pateikiau pirmiausia todèl, kad būtent siūlomasis „žiniatinklis“ (žinių + tinklas) nurodo WWW turinị; tad, reikia pasiaiškinti, ar tikrai WWW turinys visada yra žinios. Paaiškejja, kad kartais WWW turinys yra ne tik kad ne „žinios“, bet netgi „žinių“ priešybė (nežiūrint kokia bendrinès kalbos žodynų 
prasme „žinias“ mėgintume interpretuoti: žinios, informacija ar naujienos); tad ir toks terminas - kaip WWW lietuviškas atitikmuo - nenaudotinas. ... Jei pasaulinio tinklo esmè yra jo globalumas - tai ir verskime „WWW, Web“ -> „pasaulinis (ar „globalus“) tinklas“, o ne „žiniatinklis" ... [kom. 2008].

- Blog žodis atsirado apjungus du anglų kalbos žodžius „web“ ir „log“. Web - tinklas, log - lèktuvo, laivo, radijo stoties žurnalas kuriame fiksuojami įvykiai. „Web log“ arba kaip dažnai ir iškreiptai sakoma „blog“ yra ne kas kita, kaip interneto tinkle patalpintas įvykių žurnalas (registras), kuris paprastai lietuviškai, be jokių išsidarinėjimų ir naujų žodžių kūrimo vertètų vadinti dienoraštis arba elektroninis dienoraštis [kom. 2012].

3.1. Pabrèžtina, kad internetiniam naujažodžių diskursui, apimančiam reikšmès aiškinamųjų ir vertinamųjų MK blokus, būdingas naujausių interneto technologijų igalintas [27] interaktyvumas. Tokie MK gali rastis kaip grandininè reakcija (11) i straipsnyje pavartoją naujažodi - naująji skolinị (a) ar naująji darinị: pavartotą kaip naujojo skolinio atitikmenị (b) arba nesusijusị su skoliniu naujadarą (c), be to, skirtingai nei informacinejje erdvejje, čia net ir reikšmès aiškinamieji MK paprastai esti atsakas i konkretų diskurso dalyvio klausimą, o ne tekstą suvokti padedanti metakalbinė informacija, skirta hipotetiniam adresatui, pvz.:

- $\quad$ a) DJ_LFS: kas yra per keiksmazodis podkastas? simts podkastu! podkast! alia podkast kaip susizeidziau ranka, nu podkast!

- Kionig, moderatorius: Ne keiksmazodis, o cia informatiku terminas, o greiciau pas lietuvius tapes slengu, nors ir sitas zodis kaip ir neverciamas ir nera zodynuose, galima manyti kad kazkoks pasaulinis zargonas. Podcastinga reiktu isivaizduot kaip transliavima, kadangi artimesnis zodis jam yra broadcast, o kas reiskia transliacija. Nors is tikruju straipsnyje [abu komentarai yra atsiradę kaip atsakas ị straipsnị „Tele2 podkastus mobiliuoju internetu išbandè 206 tūkst. vartotojų - J. G.] buvo parasyta kas yra podkastas. Aha ir kur dydyjy kalbynynkai, kai reikia sugalvoti atitinkamus atitikmenis, o ne juoka keliancius zodzius. Matyt, perdaug sudetinga jiem tuos zodzius versti ir ieskoti analogu.

- Impintinas: Kionigai, dažniausia net ne kalbininkai sukuria lietuviškus atitikmenis, o tos srities specialistai (atsimeni vaizduokli - informatikai jị ir pasiūlè). Vietoj piktinimosi galètum imt ir savo variantą pasakyt, nes piktintis bet kas gali [kom. 2010].

- b) Vakar žiauriai neturẻjau laiko, todèl šiandien tebus tinklaraštyje du įrašai. Nuolatiniai VZ.LT lankytojai žino, kad pažadẻjau būti kasdien (išskyrus komandiruotes ir kitas stichines nelaimes :-)) [inf. (tinklaraščio straipsnis, vklase) 200702 27].

- deja_voodoo, 200702 27, 05:31: o! tinklaraštis. neblogai neblogai, netgi visai gerai)

(11) Tyrimai rodo, kad tokia reakcija apskritai būdinga internetiniams komentarams kaip žanrui: jie apima ne tik skaitytojų nuomones apie komentuojamą straipsnį ar jame aptariamus dalykus, bet ir apie jau pareikštas skaitytojų nuomones, atsakymus tų skaitytojų, kurių nuomonės susilaukẻ komentarų ir pan. $[22,4 ; 23,58]$. 
- $\quad$ vklase, 200702 27, 05:33: „blog u s“ didž. gerb. lietuvių kalbos komisija tik ką uždraudè. Juk reikia kažką daryti..:-)

- deja_voodoo, 200702 27, 05:41: bet tai [tinklaraštis ] geresnis variantas nei el. dienoraštis, juolab turime ir tinklažmogị

- $\quad$ vklase, 200702 27, 05:45: tuosyk einu i vlkk.lt diskusijų skyrelį padèti trigrašį i diskusijas ... [kom. 2007].

- $\quad$ c) Visada kirbejjo mintis, kad auto.plius.lt atsinaujins. ... Panašu, kad plius.lt grupé, Lietuvos interneto padangeje užimanti ketvirtą vietą pagal realių vartotojų skaičių ir vartotojų pasiekiamumą ... smarkiai padirbèjo. Atsinaujino visas plius.lt - „didžiausias skelbimų n a u da tinklis Lietuvoje. Naudingi skelbimai pirkti ir parduoti“ (pagal „title”) :) Pataisykite, jei klystu, tačiau panašu, kad auto.plius.lt tapo visas Ajax'inis, t.y. buvo atnaujintas portalo sistemos branduolys ... [inf. (forumo straipsnis „Senas ar atsinaujinęs auto.plius.lt?“" kaip atsakas ị atnaujintą svetainès plius.lt savireklamą; ji šio straipsnio autoriaus pateikta kabutèse) 2009].

- Marius, 200904 28, 10:38: Tiesa, su tuo „nau d a tin kliu“ ... kas čia per ịdomi komunikacijos strategija? Ar tai didelis noras palikti randą Lietuvių kalbos žodyne ar yra apčiuopiamos naudos iš tokių žodžių: nau datinklis, skelbraštis ir t. t. :) Žodyne tokių neradau :).

- Vytas, 200904 28, 11:07: Paaiškinimas Martynui: naudatinklis - naudos tik sau siekianti interneto svetainè. Panašiai, kaip LEO LT. Irgi naudatinklis. <...>

- Kentas, 200904 28, 17:07: Brangieji, zodziu „nau datinklis“ norima pasakyti, kad daroma viskas, kad Jums butu geriau, patogiau, greiciau $<\ldots .>$

- Vytas, 200904 28, 17:39: Kentai, su tuo „naudatinkliu“, tai jūs pralinksminote ne vieno žmogaus gyvenimą. Ačiū už tai [kom. 2009] (12).

Tokios reakcijos $\mathfrak{i}$ straipsnio autoriaus tekste pavartotą referentinę funkciją atliekantị naujažodi gali inspiruoti ir tolesnes diskusijas, ne tik aptariančias esamus naujažodžius, svarstančias jų vertę, bet ir siūlančias savų naujų žodžių (žr. pabrauktuosius), argumentuojančias jų vertingumą, pvz.:

- ... Blogeris, 200710 31, 13:06: Šj̣ kartą atsiprašysiu autoriaus ir komentatorių, kad nekomentuosiu straipsnio. Mane labai „knisa“ pats angliško termino „blog“ tiesioginis naudojimas lietuvių kalboj, neįvertinus jo asociacijos su lietuvišku žodžiu „blogas (negeras)“ (13). ... Gal

(12) Iš viso straipsnis sulaukè 43 skaitytojų komentarų. Čia pateikti tik tie, kuriuose yra metakalbinių vienetų su aktualiu naujažodžiu.

(13) Komentuojamame tinklaraščio straipsnyje kaip realijos pavadinimas vartojamas skolinys blogas, bet svarstomi ne kalbiniai klausimai. Iš viso straipsnis sulaukè 233 skaitytojų komentarų, kurių dalyje kaip realijos pavadinimas taip pat vartojamas šis skolinys, svarstomi dažniausiai su straipsnio turiniu vienaip ar kitaip susiję klausimai. Čia pateikti metakalbinių vienetų su aktualiais naujažodžiais pavyzdžiai yra internetinių komentarų, nesusijusių su straipsnio turiniu, dalis. Tokie nuo komentuojamojo teksto visiškai nutolę komentarai būdingi ne tik naujažodžių diskursui: internetinių komentarų kaip žanro tyrimai rodo, kad, be komentarų, kurių tema daugeliu atveju yra nulemta komentuojamojo teksto, esama ir tokių, kur iš viso nuo jos nutolstama $[23,58]$. 
geriau vadinti šios rūšies elektroninę spaudą B LO GE RIA IS, dar geriau jei rastume tinkamesnị lietuvišką atitikmenị. ... Taigi, ponai ir ponios, jei tai ir jus „knisa“ pirmyn ị darbą. <...>

- Realistas, 200710 31, 14:48: Pradeti reikia nuo istaku: „blog “yra „web-log“ santrumpa. Taigi, lietuviskai butu mazdaug tinklazyme. Taciau kartais tas „blogas“ neblogai skamba... $<\ldots>$

- Saulius, 200710 31, 15:23: Gal ir taip. Tačiau blogeris dar blogiau nei blog as - labiau tiktų asmeniui, dalyvaujančiam bloge. Čia jau lietuviškesnis būtų blogietis. Žinoma, geriausia būtų radus trumpą, skambų ir lengvai įsimenamą lietuvišką žodị. Tačiau tai ir yra sunkiausia. $<\ldots .>$

- Ice, 200710 31, 22:54: Aš vis galvojau, kad tiesioginis, pažodinis vertimas, ar jo vertimo naujadaras būtų blogas:) dalykas. Bet begalvojant kad blog'as yra Tinklo dienoraštis, savaime mintyse pradèjo įkyriai skambèti "traštis“, t. y. T(inklo)+(dieno)raštis. O tai blogeris turètų būti „trašytojas" arba „trašys“: ) Taigi jūsų teismui atiduodu mano galvoje prieš 10 min. gimusį naujadarą: BLOG=TRAŠTIS.

- $\quad$ Auksinis kardas, 200711 01, 00:29: išsamu, taiklu, neturiu ką pridurti <...>

3.2. Individualūs naujadarai, paprastai inspiruoti esamų tos pačios realijos pavadinimų neigiamo vertinimo, apskritai itin būdingi naujažodžių diskurso dalyviams - jų (pabraukti) gausu ne tik straipsnių komentaruose, bet ir diskusijų forumuose (pvz., http://www.vlkk.lt/ lit/diskusijos):

- $\quad$ Pervadinome webmasterị ... demokratiškai, su svetainès autoriais pasitardami išrinkome naują vardą. Dabar anas vadinasi svetainès prižiūrètoju ... Nors man asmeniškai labiau būtų patikęs tinklavaldžio ar kokio tinklavedžio terminas ... Kita vertus, svetainés prižiürètojas pakankamai tiksliai ịvardija funkcijas. Taigi, vienintelis trūkumas - ilgumas [kom. 2007].

- $\quad$ Visatinklis. ... „Žiniatinklis“ - negerai, nes ne vien žinios. Šaknis „vis“ neblogai atitinka „world-wide“ [kom. 2009].

- $\quad$ [Žiniatinklį] Nesunku patrumpinti iki ŽINTINKLIO. Sutaupom vieną skiemenị. Jaučiant kontekstą galima vadinti TINKLU - Web [kom. 2008].

- Jeigu tą „bloggerį“ pavadintume tinklarašeiva. O jeigu pamėgintume sujungti žodžius internetas+saitas-(ininkas), na panašiai kaip apskaitininkas, gautume inter(net)sai$\underline{\text { tininkas, }}$ intersaitininkas arba / tinklasaitininkas, o gal saitraštininkas [kom. 2009].

Forumų dalyviai, svarstydami rekomenduojamų vartoti naujų žodžių vertę, pateikia ne tik naujažodžių, jų nuomone, tinkančių referentinei funkcijai atlikti - realijai įvardyti, bet ir metakalbinę bei emocinę ekspresinę funkciją atliekančių ironiškų ar žaismingų stilistiškai ekspresyvių naujadarų (pabraukta) - pastarieji, kaip jau minėta, patys neretai tampa MK dalimi, pvz.: 
- Visai neseniai buvau apsviestas, kad interneto vartotojus reikia vadinti TINKLININKAIS - nu cia tipo lietuviskai, tiesa yra ir internautai; bet vis delto, kyla klausimas, o kodel, pvz., ne rankininkai??? juk narstant nete, daugiausia dirbama rankomis. jooo... mano galva, sakyciau visu tinkamiausias terminas is vis butu pelegniauzininkai:) nors gal tiksliau situom terminu vadinti apskritai kompiuterininkus:), o kompiuterija - pelegniauzyste? [kom. 2005].

- Man geriausiai skamba 'internetinis dienorastis' apskritai (: o visokie ten asmenrasciai mintinklarasciai ir kiti sudurtizmai labai jau tragiskai skamba, kaip ir is situ sudurtizmu padaryti dar ir tolesni naujadarai (: [kom. 2008].

- Lietuviškas žodis „pasaulis“ yra nuo „po saule“. Tai blogosfera būtų tai kas yra po tinklaraščiais. Na tai kaip ir patinklaraštyja. Taip, noriu, kad liežuvị nusilaužtumète :) [kom. 2009].

Naujažodžių diskursui būdingas ironiškas žaismingumas nestebina - žaismè, kalbinis žaidimas yra laikomas postmodernybès epochos, kuriai apskritai labai būdingi naujažodžiai, išskirtiniu bruožu [20, 32 ir t. t.].

3.3. Reikšmès aiškinamieji ir vertinamieji MK dažnai randasi ne tik kaip reakcija ị ivairios tematikos straipsniuose pavartotus naujažodžius, bet ir kaip atsakas į kalbinius kausimus svarstančius straipsnius, juose vartojamų MK atgarsis (panašiai kaip vienas kitą papildantys kalbinių diskusijų forumų dalyvių komentarai); ir tokiais atvejais naujažodžių diskurso dalyviai dažnai pasitelkia metakalbinę bei emocinę ekspresinę funkciją atliekančių naujadarų (pabraukti), pvz.:

- Vakar rašydamas straipsnị apie internetinius komentarus ne vieną kartą panaudojau žodị tinklaraštis. Prisipažinsiu, kad labai dažnai nesusimąstydamas blogus vadindavau tinklaraščiais. Tačiau šiandien susimąsčiau, kad šis žodis neturi nieko bendro su blogu - žodžiu, kurị kalbininkai, mano nuomone, netinkamai pabandè sulietuvinti. Visada stengiuosi rašyti taisyklinga lietuvių kalba, bet tokių žodžių kaip vaizduoklis (monitorius), žin ia tinklis (internetas) ... niekada neapsiverstų liežuvis naudoti gyvojoje kalboje. Tai kodèl turèčiau taip rašyti. Žinoma, gerai kad kalbininkai stengiasi išsaugoti unikalią lietuvių kalbą. Tačiau bandydami sulietuvinti techninius terminus dažnai prasilenkia su elementaria logika. Manau, kad techninių terminų vertimu turètų užsiimti ne patys filologai, o tos srities profesionalai. Kad ir žodis žiniatinklis (angl. Web). Juk jau seniai internetas tapo ne tik žinių šaltiniu, bet ir atskira verslo ar pramogų šaka ... Mano nuomone, lietuvių kalbininkai galètų pasinaudoti kitų šalių praktika ir daugelị techninių terminų ne versti, o sulietuvinti (pridèti žodžių galūnes). Jeigu pačiam reikètų pradèti skaityti techninę literatūrą (paprastai susijusią su kompiuteriais) lietuvių kalba, tikriausiai tektų išmokti daug naujų žodžių. Beje, pasinaudodamas Google Translate, patikrinau kaip verčiamas angliškas žodis Blog i kitas kalbas. Daugumoje kalbų buvo paliekamas tas pats žodis [inf. (tinklaraščio straipsnis „Tinklaraštis ar blogas?", Evaldas) 2010].

- Mantas, 201002 25, 18:28: Kalbininkai bando kurti lietuviškus atitikmenis, bet atsisako jų, jei neprigyja. Nematau nieko čia blogo. Vaizduoklio prieš pusmetį buvo oficialiai atsisakyta (be to, èjo kažkokios paskalos, kad ji net ne kalbininkai pradejjo vartot). Jei gerai pamenu mo- 
kyklos informatikos pamokas, žiniatinklis ir internetas nèra tas pats, taigi čia nelabai ir atitikmuo. Berods žiniatinklis siauresnè sąvoka, apimanti tik naršymą su naršykle, bet čia galiu ir klyst ... Dèl blogo. Rastas visai gražus atitikmuo, kuris baigia prigyti, tai čia nèra jokios problemos. Aišku, pripažįstu, kad daugelyje vietų kalbininkai persistengia ir nusivažiuoja ị lankas, bet ką padarysi. Neklysta tik nieko nedarantys. Ir Lietuvoje čia dar viskas normaliai. Brolis Islandijoj uždarbiauja, tai pasakojo, kaip jie ten iš viso tarptautinių žodžių nevartoja, o kuria grynai naujadarus. Va ten tai jau sunku žmonèms susigaudyt:) [kom. 2010].

- $\quad$ Evaldas, 201002 25, 18:55: Dèl žiniatinklio - nežinau ar tai siauresnè sąvoka už in ter netą, ar ne, bet niekada jos nenaudojau ir nenaudosiu, nes žmonèms atneša daug neaiškumų...

- Tomas, 201002 26, 18:56: Tai, kas lietuviškai vadinama žiniatinkliu, angliškai vadinama world wide web'u (kuris naršomas naršykle), o ne internetu. Internetas yra daug platesné sąvoka bei taip pat jau daug senesné nei www. O tinklaraštị kartais ne patys blogeriai sugalvojo? Aš tai net nepastebejjau kai visi ji pradèjo vartoti.

- $\quad$ reanimated, 201002 25, 18:32: Pasak valstybinę lietuvių kalbos komisiją netinka nei žodis tinklaraštis, nei blogas. Reikia naudoti saitukas:).

- $\quad$ Evaldas, 201002 25, 18:50: Arba portaliukas, arba puslapiukas:).

- Ligita, 201002 25, 19:37: reanimated, o kur tu čia radai tokią informaciją, kad netinka tinklaraštis? Akivaizdu, kad juokauji:) Pavyzdžiui, aš atsiverčiau ir prašom rezultatas - http://www.vlkk.lt/lit/4971 Bet vis vien niekaip nesuprantu kodèl kai kuriems kliūva žodis tinkla raštis. Labai gražus žodis, kurị vartoju ir šnekèdama.

- Evaldas, 201002 25, 19:46: Ligita, taip žodis labai gražus, bet kažin ar reiškia tą patị kaip ir originalas. Beje, tinklaraščio žodžio daryba sudetinga. Kaip pavadinti tinkla raščio autorių - tinklaraštininką. Beje, kažkur pas save buvau panaudojęs šį terminą:).

- Altajus, 201002 25, 19:42: Pritariu Ligitai, ko tas „tinklarašti i“ jums kliūva. Normalus žodis. Visada stengiuosi ji naudoti. Kažkas jau buvo iškèlęs panašią diskusiją. Komentarai pasidalino per pus. Vieni vartoja šş žodị, kitiems jis netinka. Aš sakyčiau, tai labiau skonio reikalas. Pritariu tik dèl Vaizduoklio:).

- $\quad$ Eugenijus, 201002 25, 20:19: Man ir nekliuva tinklarastis:) Nors retokai naudoju si zodi - per ilgas ir gremezdiskas ... bet lietuviskas:).

- Valentina, 201002 26, 9:2: Pritariu dèl tinklaraščio. Nors kartais tenka pavartoti ir blogas. tačiau, kaip ir altajus, vaizduoklio nesupratau:) Beje, kiek žinau, žiniatinklis, kaip Mantas ir sakè, turi siauresnę prasmę. Dar klausimas - kažkada viename pristatyme girdẻjau žodị „saitynas“. Ar jis jau oficialiai vartojamas lietuvių kalboje? Išgirdus išsigandau, tiesa pasakius.

- Evaldas, 201002 26, 9:38: Panašu, kad jau naudojamas: http://www.vlkk.lt/lit/88519. Bet skamba kaip XIX a. pab. knygų platinimo organizacija Sietynas:). 
- Mantas, 201002 26, 18:59: Taip, berods kažkas iš vietinių šitą žodị sugalvojo, aš irgi tokių kalbų esu girdèjęs:).

- $\quad$ Evaldas, 201002 26, 19:47: Pagal VLKK dabar reikia sakyti ne žiniatinklis, o saitynas (http://www.vlkk.lt/lit/88519) :).

- $\quad$ Arvydas, 201002 27, 1:24: Man labiausiai nepatiko modemo atitikmuo - vertiklis, o prieš tinklaraščio vartojimą iš pradžių buvau nusiteikęs neigiamai, tačiau dabar nesu. Tik tas tinklaraštininkas labai jau gremėzdiškai skamba, blogeris daug smagiau.

- Margariux, 201002 28, 10:27: Aš už žodi „Tinklar ašti s“, man daug gražiau skamba nei blogas, šią savaitę, važiuojant per radiją kažkas kažką kalbèjo ir vis minejjo žodį „Blogas“.. nju man kažkaip jau atrodo nevartotinas tas žodis. B-log, tai nelietuviška. Tinkla raštis man labiau patinka [kom. 2010].

Tokie kalbos vartotojų interakcijos nulemti metakalbinių vienetų blokai - specifinis būtent interneto erdvei būdingas reiškinys, geriausiai reprezentuojantis internetinị naujažodžių diskursą.

3.4. Metakalbiniai vienetai su kalbos vartotojų MK ir jų blokai neabejotinai laikytini svarbiu internetinio naujažodžių diskurso elementu (14). Metakalbinių naujažodžių komentarų gausa patvirtina ankstesniuose MK pagrịstuose tyrimuose minimą kalbos vartotojų polinkị pastebėti būtent leksikos naujoves - ypač konkuruojančias, ịvardijančias naujus gyvenimo reiškinius [plg. 31, 127, 129-130]. Tai rodytų naujažodžių svarbą kalbinei bendruomenei, jos sieki aktyviai dalyvauti kalbos kūrimo procese. Kertiniai naujažodžių diskurso klausimai - iš(si)aiškinti naujų žodžių reikšmę ir aptarti jų vertę - iš esmès atitinka nurodytuosius lietuvių kalbos vartotojų MK, kurių objektas yra žodis, tyrime [plg. 32, 390 ir kt.]. Tokie tyrimų rezultatai liudytų lietuvių kalbinei bendruomenei rūpimus dalykus esant universalius - panašūs klausimai minimi ir kitų kalbų tyrejjų darbuose: tekstų autoriai, jausdami pristatomą realiją esant naują, skaitytojams paprastai paaiškina ją ịvardijantị naujažodị, svarsto jo tinkamumą sąvokai įvardyti [12, 249].

MK dažniausiai palydimi visuomenei svarbias interneto realijas pavadinantys aktualesni naujažodžiai - dèl skolinių norminimo tradicijos radęsi leksikos konkurentai, kuriais ịvardijamas dalykas yra pažistamas didelei kalbinès bendruomenès daliai, o jie patys - dažnos vartosenos, pvz., blogas / tinklaraštis. Bendrašaknių skolinių ir atitikmenų atveju daugiausia kalbos vartotojų reakcijos paprastai sulaukia pirmasis pasiskolintas pamatinis žodis ir jo atitikmenys, dažniausiai įvardijantys daikto pavadinimą, ir vienas kitas tai paradigmai svarbus vedinys - dažnai tai yra veiksmo atlikejjo pavadinimas (blogeris / tinklaraštininkas ir kt.). Kitų bendrašaknių žodžių reikšmė kalbos vartotojams, ippratusiems prie minètụjų pagrindines paradigmos sąvokas ịvardijančių naujažodžių, paprastai jau būna aiškesnè, neịprastumas, akiai ir ausiai pripratus prie šių naujažodžių kamienų, mažesnis.

Konkrečius skolintus ir lietuviškus naujosios leksikos konkurentus aptariantys MK ir jų blokai atskleidžia ir bendrą kalbos vartotojų požiūrị ị naujųjų skolinių norminimą. Nors esama ir atvirai deklaruojančiųjų grynumo kriterijaus svarbą, naujažodžio lietuviškumą

(14) Naujažodžių diskursui priskirtina ir elektroninèje terpèje pateikiama kalbininkų nuomonè apie naująją lietuvių kalbos leksiką. 
laikančiųjų savaimine vertybe, ir apskritai nepritariančiųjų skolinių vengimo strategijai, taigi ir lietuviškų atitikmenų paieškai, vis dẻlto akivaizdu, kad naujažodžių diskursui būdingesni lietuviškų variantų kokybès, o ne reikalingumo klausimai. Nors apie tą patị naujažodi galima rasti ir teigiamų, ir neigiamų atsiliepimų, vis dèlto MK visuma leidžia ižvelgti bendrą kalbinès bendruomenès vertinimo vaizdą. MK tyrimo rezultatai rodo, kad internetinị naujažodžių diskursą plètojanti kalbinẻ bendruomenẻ kaip visuma geba argumentuotai vertinti ir pati siūlyti naujažodžius - tai koreliuoja su kitų tyrimų rezultatais: nustatyta, kad vartosenoje įsigali funkcionaliausi leksikos variantai. Žiniatinklio realijas įvardijančių naujažodžių vertę nusakančių MK analizė liudija, kad kalbos vartotojų nurodomi lietuviškų variantų privalumai ir trūkumai iš esmès atitinka Bendruosiuose naujuju skoliniu norminimo principuose, kurie parengti remiantis nuodugniais naujųjų skolinių ir jų atitikmenų vartosenos tyrimais [žr. 7; 30], pateiktus atitikmenų vertinimo kriterijus: naujojo skolinio atitikmuo turètų būti sistemiškas, darus, ekonomiškas, aiškios motyvacijos, jo reikšmè - adekvati skolinio reikšmei [plačiau žr. 3]. Tik toks naujažodis turi galimybių realiai prigyti, tapti tikru žodžiu, t. y. iš pasyviojo leksikos fondo pereiti $\mathfrak{i}$ aktyvųji. Taigi MK tyrimas dar kartą patvirtino tai, kad kalbos vartotojai kaip visuma iš daugybės naujovių neabejotinai geba pasirinkti visuomeniškai tikslingiausias, funkcionaliausias [plg. 7, 126-127]. Nors vieni MK autoriai atsakingais už lietuviško pavadinimo tinkamumą laiko kalbininkus, kiti, dažnai oponuodami šių nuomonei, teigia terminus kuriant tam tikros srities specialistus, patys MK autoriai, kaip globalaus tinklo įvairiažanrių tekstų kūrèjai - tinklaraštininkai, komentarų autoriai ir kt., aktyviai ịsitraukia ị interneto realijas ịvardijančių atitikmenų paiešką, kūrimą ir sklaidą - tai gerai matoma naujažodžių diskurso dalis. Taigi interaktyviame tinkle vadinamasis kalbos vartotojas tampa aktyviu kalbos kūrèju. Nors pasitaiko MK, kuriuose leksikos konkurencijos baigtis siejama su vieno ar kito naujažodžio įtraukimu į žodyną ar pan., vis dèlto ryškesnis vartotojų kaip visumos, vadinamosios vartosenos, lemtingo leksikos variantų atrankos vaidmens leitmotyvas. Taigi kalbinès bendruomenès nuomonè sutampa su profesionalų: visuotinai sutariama, kad galutinis leksikos variantų atrankos kriterijus yra vartosena [7]. Beje, pažymètina, kad MK atsispindi viešosios ir privačiosios vartosenos, profesinio žargono, skirtis.

MK radimasis ir gausejjimas sietinas su naujažodžio socializacijos ir leksikalizacijos, t. y. plètros vartosenoje ir įsitvirtinimo kalbos sistemoje $[34,15]$, procesų pradžia. Pavieniai MK ir jų blokai yra tarsi naujažodžio reklaminė ar antireklaminè akcija, padedanti žodžiui plisti arba užkertanti tam kelią, dažnai inspiruojanti tolesnị naujadaros procesą (esamais realijų pavadinimais nepatenkinti naujažodžių diskurso dalyviai tampa naujų žodžių autoriais). MK dingus (sinchroninès vartosenos diachroninis pjūvis) galima daryti prielaidą, kad naujažodis, priklausęs pasyviajam leksikos fondui, perèjo ị aktyvųji, tapo tikru leksikografiškai įformintinu žodžiu (išskyrus naujųjų skolinių, kuriuos bent jau iš formalesnès viešosios vartosenos išstūmė tinkami lietuviški atitikmenys, atvejus). Pavyzdžiui, vienas labiausiai komentuojamų tiriamosios imties naujažodžių - tinklaraštis - kaip pavienis MK objektas užfiksuotas 2005 m., masiškiau pradètas komentuoti nuo 2007 m. (tais metais ima plisti ir vartosenoje), o nuo $2009 \mathrm{~m}$. šio naujažodžio MK mąžta. Tai koreliuoja su vartosenos tyrimų rezultatais: $2008 \mathrm{~m}$. pabaigoje teigiama ši naujažodị jau buvus paplitusị viešojoje vartosenoje, taigi ir informacinèje interneto erdvejje, o komunikacinejje - sékmingai konkuruojantị su sinoniminiu naujuoju skoliniu blògas [10]. 


\section{IŠVADOS}

1. Kalbos vartotojų internete pateiktų metakalbinių komentarų, kurių objektas yra žiniatinklio realijas įvardijantys naujažodžiai - naujieji dariniai su elementu (-)tinkl- ir ịvairiašakniai dubletiniai naujieji skoliniai bei kiti sinoniminiai jų atitikmenys, kokybinès analizės rezultatai liudija MK esant neabejotinai svarbų internetinio naujažodžių diskurso elementą, atskleidžiantị leksikos pokyčių svarbą kalbinei bendruomenei, jos siekį aktyviai dalyvauti kalbos kūrimo procese.

2. MK dažniausiai palydimi visuomenei svarbias interneto realijas įvardijantys referentinę funkciją atliekantys aktualesni naujažodžiai - dèl skolinių norminimo tradicijos radęsi dažnesnès vartosenos leksikos konkurentai: naujieji skoliniai ir naujaisiais dariniais išreikšti lietuviški jų atitikmenys, pvz., blògas / tinklaraštis. Neformaliai komunikacinei interneto erdvei, kaip ir apskritai postmodernizmo epochai, būdingi naujažodžiai, kurių pagrindinė funkcija emocinè ekspresinè, retai tekomentuojami - jie dažniau patys tampa žaismingo ar ironiško MK dèmeniu.

3. Lietuvių kalbinei bendruomenei, kaip ir kitų kalbų vartotojams, svarbu iš(si)aiškinti naujažodžių reikšmę ir aptarti jų vertę.

3.1. Informacinei interneto erdvei, apimančiai elektroninių svetainių ir tinklaraščių straipsnius, būdingiausi tekstą atkoduoti padedantys, naujažodžių reikšmę aiškinantys $\mathrm{MK}$ vertintini kaip naujų žodžių integracijos ị tekstą būdas: naujųjų skolinių atveju metakalbiniais sumetimais nurodoma originalo forma, pamatinių žodžių reikšmé, pateikiamas jais ịvardijamų realijų apibūdinimas, o vèliau vartosenoje pasirodę naujaisiais dariniais išreikšti jų atitikmenys dažniausiai aiškinami adresatui jau tapusiais ịprastais skoliniais.

3.2. Komunikacinei interneto erdvei, apimančiai diskusijų forumų, straipsnių komentarus ir pan., būdingiausi naujažodžių vertę aptariantys MK, kurių pagrindinis tikslas - išdiskutuoti naujažodžio tinkamumą realijai ịvardyti.

3.3. Specifinis internetinio naujažodžių diskurso bruožas - jo dalyvių interakcijos nulemti informacinę ir komunikacinę erdvę susiejantys metakalbinių vienetų blokai su naujažodžių vertės aptariamaisiais ir, paprastai kaip pagalbiniais, jų reikšmės aiškinamaisiais MK.

4. Interneto realijas ịvardijantys naujažodžiai - ir naujieji skoliniai, ir kaip jų atitikmenys siūlomi naujieji dariniai - sulaukia tiek teigiamų, tiek neigiamų kalbos vartotojų vertinimų. Vertès aptariamieji MK rodo kalbos vartotojams esant svarbų naujažodžio (ne)lietuviškumą, motyvacijos aiškumą, ekonomiškumą, estetiškumą, vartojamumą ir kt.

4.1. Neigiamo vertinimo MK dažnai inspiruoja tolesnị naujadaros procesą: diskurso dalyviai, svarstydami esamų skolintų ar lietuviškų naujažodžių vertę, pateikia savų sinoniminių naujadarų, teigiamo vertinimo MK argumentuodami pastarųjų vertingumą.

4.2. Konkrečius skolintus ir lietuviškus naujosios leksikos konkurentus aptariantys MK atskleidžia ir kalbos vartotojų požiūrị i naujųjų skolinių norminimą apskritai. Nors esama ir naujažodžio lietuviškumą laikančiųjų savaimine vertybe, ir apskritai nepritariančiųjų lietuviškų atitikmenų paieškai, vis dèlto akivaizdu, kad naujažodžių diskursui būdingesni lietuviškų variantų kokybès, o ne reikalingumo klausimai. Su panašiais vartosenos tyrimų duomenimis koreliuojantys MK analizès rezultatai rodo kalbinę bendruomenę gebant argumentuotai vertinti naujažodžius - iš daugybės leksikos naujovių pasirinkti visuomeniškai tikslingiausias, funkcionaliausias.

4.3. Ryškus internetinio naujažodžių diskurso dalyvių pateikiamų MK motyvas - asmeninès iniciatyvos ir atsakomybès už žodyno kūrimą prisièmimas, vartosenos - kalbos 
vartotojų visumos - kaip leksikos variantų konkurencijai lemtingo vaidmens suvokimas. Interaktyviame tinkle vadinamasis kalbos vartotojas tampa savo indèli suvokiančiu, jo poveikị stebèti galinčiu aktyviu kalbos kūrèju.

5. MK radimasis ir gausèjimas signalizuoja naujažodžio socializacijos ir leksikalizacijos procesų pradžią, o išnykimas - pasyviajam leksikos fondui priklausiusị kalbinei bendruomenei svarbią realiją ịvardijantị dažnos vartosenos naujažodi perẻjus ị aktyvųji leksikos fondą, tapus leksikografiškai įformintinu žodžiu, išskyrus iš viešosios vartosenos išstumtų tą pačią realiją ịvardijančių naujažodžių poros narių, paprastai naujųjų skolinių, atvejus.

Gauta 20120829

Priimta 20120906

\section{Literatūra}

[1] ÄDEL, Annelie. Just to give you kind of a map of where we are going: A Taxonomy of Metadiscourse in Spoken and Written Academic English. Nordic Journal of English Studies [interaktyvus], 2012, 9(2), p. 69-97 [žiūrèta 201204 01]. Prieiga per internetą <http://ojs.ub.gu.se/ojs/index. $\mathrm{php} / \mathrm{njes} /$ article/view/415/403>.

[2] BECHERT, Johannes; WILDGEN, Wolfgang. Einführung in die Sprachkontaktforschung. Darmstatt: Wissenschaftliche Buchgesellschaft, 1991.

[3] Bendrieji naujuju skoliniu norminimo principai [interaktyvus], 2007 [žiūrèta 201206 15]. Prieiga per internetą <http://www.vlkk.lt/lit/88922>.

[4] BROKARTAITĖ-PLADIENĖ, Indrè. Vokiečiu kalbos naujažodžių perteikimas laikraštyje „Naujasis Tilžès keleivis“ (1924-1940). Respectus Philologicus, 2009, 15(20), p. 180-191.

[5] ENGLEBRETSON, Robert. Metalinguistic commentary in a planned language: prescriptive remarks in Indonesian conversation. 9th Annual Conference on Language, Interaction, and Culture - Conference Poster: The University of California, Santa Barbara [interaktyvus], 2003 [žiūrèta 201203 10]. Prieiga per internetą <http://orgs.sa.ucsb.edu/liso/AbsHTML/Englebretson.html>.

[6] GIRČIENĖ, Jurgita. Neologizmų integracija ị tekstą. Žmogus ir žodis [interaktyvus], 2005, 1(7), p. 78-82 [žiūrèta 201205 01]. Prieiga per internetą <http://www.biblioteka.vpu.lt/zmogusirzodis/PDF/didaktinelingvistika/2005/girciene.pdf>.

[7] GIRČIENĖ, Jurgita. Naujujų skoliniu atitikmenys: struktūra ir vartosena. Vilnius: Lietuvių kalbos instituto 1-kla, 2005.

[8] GIRČIENĖ, Jurgita. Verstinès literatūros naujažodžiai. Kalbos kultūra [interaktyvus], 2006, 79, p. 74-90 [žiūrèta 201206 20]. Prieiga per internetą <http://archive.minfolit.lt/arch/2501/2817. $\mathrm{pdf}>$.

[9] GIRČIENĖ, Jurgita. Naujųų skolinių vartosena: kalbos kultūros ir stilistikos takoskyra. Kalbos kultūra, 2007, 80, p. 143-152.

[10] GIRČIENĖ, Jurgita. Naujieji svetimžodžiai su šaknimi blog- ir jų atitikmenys. Kalbos kultūra, 2008,81 , p. 50-64.

[11] GIRČIENĖ, Jurgita. Naujažodžiai su dèmeniu (-)tinkl-. Kalbos kultūra, 2011, 84, p. 165-177.

[12] GRAEDLER, Anne-Line. Morphological, Semantic and Functional Aspects of English Lexical Borrowings in Norwegian. Oslo: Scandinavian University Press, 1998.

[13] GRANT-RUSSELL, Pamela. The influence of French on Quebec English: motivation for lexical borrowing and integration of loanwords. LACUS Forum 25. Claremont Graduate University, The Linguistic Association of Canada and the United States, 1999.

[14] GUDAVIČIUS, Aloyzas. Etnolingvistika. Šiauliai: K. J. Vasiliausko įmonè, 2000. 
[15] YANG, Jian. Lexical innovations in China English. World Englishes [interaktyvus], 2005, 24(4), p. 425-436 [žiūrèta 201203 20]. Prieiga per internetą <http://www.corpus4u.org/forum/upload/ forum/2005112309524237.pdf>.

[16] JAKAITIENĖ, Evalda. Leksikologija. Vilnius: Vilniaus universiteto l-kla, 2010.

[17] JAKOBSON, Roman. Lingvistika ir poetika. Baltos lankos, 2004, 18/19, p. 5-49.

[18] KARALIŪNAS, Simas. Kalba ir visuomené. Psichosociologiniai ir komunikaciniai kalbos vartojimo bruožai. Vilnius, 1997.

[19] KEINYS, Stasys. Lietuvių kalbos hibridai (sąvoka, rūšys ir normiškumas). Lietuvos TSR Mokslu Akademijos darbai, 1984, 3(88), A serija, p. 113-124.

[20] LYOTARD, Jean-François. Postmodernus būvis. Vilnius: Baltos lankos, 2010.

[21] MACIENĖ, Jurgita; ŽUPERKA, Kazimieras. Kalbinès raiškos švelninimo komentarų vartojimas. Filologija, 2007, 12, p. 55-65.

[22] MARCINKEVIČIENĖ, Rūta. Apie komentatorius ir komentarus. Akiračiai, 2005, 7, p. 4.

[23] MARCINKEVIČIENĖ, Rūta. Internetinių straipsnių komentarai žanriniu aspektu. Filologija, 2006, Nr. 11, p. 57-60.

[24] MIKELIONIENĖ, Jurgita. Naujoji lietuviu kalbos leksika (daktaro disertacija). Kaunas, 2000.

[25] MIKELIONIENĖ, Jurgita. Šiuolaikiniai metodai kalbos naujovems tirti. Darbai ir dienos, 2000, 24, p. 65-88.

[26] MORKEVIČIUS, Vaidas. Socialiniu vertybiu raiška politiniame diskurse (daktaro disertacija), Kaunas, 2005.

[27] NEVINSKAITĖ, Laima. Šiuolaikinès medijos ir masinés komunikacijos teorijos. Vilnius: Petro ofsetas, 2012.

[28] OFFORD, Malcolm. French Words: Past, Present and Future. Clevedon: Multilingual Matters, 2001.

[29] URBUTIS, Vincas. Žodžiu darybos teorija. Vilnius: MELI, 2009.

[30] VAICEKAUSKIENĖ, Loreta. Naujieji lietuvių kalbos svetimžodžiai: kalbos politika ir vartosena. Vilnius, 2007.

[31] ŽUPERKA, Kazimieras. Kalbos dabartiškumo nuorodos nelingvistiniuose tekstuose. Lietuviu kalbotyros klausimai / Acta Linguistica Lithuanica, 2000, 42, p. 124-130.

[32] ŽUPERKA, Kazimieras. Nekalbininkų požiūris ị žodžio vartojimą. Vārds un tā pētī̌sanas aspekti: Rakstu krājums 8. Liepāja: Liepājas Pedagoǵijas akadēmija, 2004, p. 390-395.

[33] ŽUPERKA, Kazimieras. Metakalbiniai asmenvardžių komentarai nelingvistiniuose tekstuose. Kalbos kultūra, 2006, 79, p. 62-73.

[34] ЗАБОТКИНА, Вера. Новая тексика современного английского языка. Москва: Высшая школа, 1989.

[35] ПОПОВА, Татьяна; РАЦИБУРСКАЯ, Лариса; ГУГУНАВА, Дмитрий. Неология $u$ неография современного русского языка, Москва: Наука, 2005. 
JURGITA GIRČIENE்

\title{
Metalinguistic comments as an element of Internet discourse on neologisms
}

\author{
Summary
}

The object of the article is metalinguistic comments of language users on neologisms found in the Internet. The article analyses comments on new derivatives with the element (-)tinkl- (tinklas 'network') and alternative new borrowings of various roots, as well as their synonymic equivalents describing phenomena of the Internet. The article raises the following and further questions about the Internet discourse on neologisms: What neologisms become the objects of metalinguistic comments? What is the purpose of these comments found in different electronic genres? How does the metalanguage of language users reflect the processes of integration of neologisms into the text, their socialisation and lexicalisation? What are the attitudes of the discourse participants towards their standardisation? How do they evaluate the quality of the borrowed and Lithuanian neologisms?

A qualitative analysis of empirical data shows that metalinguistic comments by language users are, beyond a doubt, an important part of the Internet discourse on neologisms. The object of the biggest amount of metalinguistic comments is those neologisms that serve the referential function of describing important phenomena of the Internet. Particularly discussed are the competing lexical alternatives: new borrowings and their Lithuanian equivalents in the form of new coinages. Neologisms with the emotive and expressive functions that are otherwise typical for the informal Internet discourse (and postmodernity in general) are rarely commented - more often they are included as an element into playful and ironic metalinguistic comments.

The community of Lithuanian language users, the same way as users of other languages, are concerned with: (a) clarifying the meaning of neologisms; (b) discussing their value. In the "informational space" of the Internet (homepages, news portals, weblogs), comments explaining the meaning of neologisms and thus helping to decode the text dominate. In the "communicational space" (comments of articles and discussion forums), there are more comments discussing the value of neologisms, i. e. how well a particular neologism is suitable to describe the denoted phenomenon of the Internet.

The neologisms describing the Internet phenomena, both new borrowings and equivalent new coinages, are evaluated positively as well as negatively. The criteria that are important for language users when discussing the value of neologisms are as follows: Lithuanian vs. foreign origin, clear motivation, economy, sound, and other. The analysis of metalinguistic comments confirmed the preposition that the community of language users as a whole is able to provide reasoned evaluations of neologisms. It correlates with the results of other studies, showing that the most functional alternatives get established in the usage. As long as a neologism is accompanied by metalinguistic comments of some or another type, it means that the stages of its lexicalisation and socialisation are not yet over. When a neologism is no longer being discussed, an assumption can be made that it has become a proper lexicographically formalised word.

Key words: neologism, new borrowing, new coinage, metalinguistic comment, internet 